
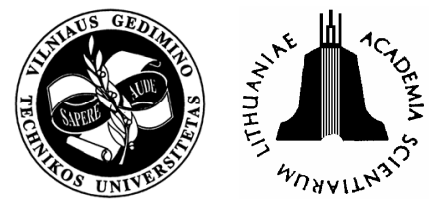

\title{
INFLUENCE OF PARTIAL SAFETY FACTORS ON DESIGN RELIABILITY OF STEEL STRUCTURES - PROBABILITY AND FUZZY PROBABILITY ASSESSMENTS
}

\author{
Zdeněk Kala \\ Brno University of Technology, Faculty of Civil Engineering, Institute of Structural Mechanics, \\ Veveři Str.95, 60200 Brno, Czech Republic.E-mail: kala.z@fce.vutbr.cz. \\ Received 02 July 2007; accepted 03 Oct 2007
}

\begin{abstract}
The paper is aimed at the analysis of the influence of partial safety factors on the reliability of designing steel members. The reliability assessment of a steel member is based on extensive experimental research on real material and geometric characteristics evaluated by samples obtained from frequently manufactured products. Material and geometric characteristics are random variables represented by histograms during the probabilistic assessment of reliability. The random variability of structural dimensions and of material characteristics does not present the only source of uncertainty present during design according to standards. The reliability of steel structures design is also dependent on the partial safety factor values, which are specified by the design standards. Partial safety factors are basic indicators, which determine structural dimensions in relation to loading. The probabilistic assessment of reliability is performed as a parametric study in the first part of the numerical analysis. The probability of failure is analysed in dependence on values of partial safety factors of material, permanent loading and long time variable loading. Partial safety factors are considered as fuzzy numbers with triangular membership functions in the second part of the numerical analysis. Membership functions of failure probability are evaluated using the general extension principle. The most important results are then summarised and additional applications of the verifications of limit states design criteria are described.
\end{abstract}

Keywords: steel, structure, design, reliability, random, fuzzy, member, imperfection, simulation.

\section{Introduction}

Common design procedures utilised during the design of real load bearing steel structures are based on the limit state methodology. Valid normative criteria emanating from the static respectively dynamic analysis of a model of the real structural system are verified when assessing of the reliability of steel structures.

The current Eurocode approach is based on the partial safety factor method, which represents basic calibration characteristics of structural design reliability. Partial safety factor values cannot be verified without knowledge of the real properties of load bearing structural members.

For this purpose material and geometric characteristic are monitored [1-3] and probabilistic assessments of steel members reliability are performed. An integral part of reliability analysis is the sensitivity analysis determining which variables the monitored output is most sensitive to and which it is not sensitive to $[4,5]$. According to our understanding, probabilistic and sensitivity studies represent an important tool for the development and verification of more sophisticated but yet simple and lucid provisions utilised in steel design practice.

The aforementioned approaches, however, only enable the quantification of uncertainties, which are of random character and for which information on the statistical characteristics from measurements on ample samples is available. A number of factors influencing reliability however are not of random character. Lately apart from classical stochastic methods other alternative approaches to the representation of uncertainty of model prediction, which include vagueness, non-specificity and conflict, are more frequently utilised. They are investigated within the framework of five theories, within which the apparatus for their quantification is developed (the crisp set theory, fuzzy set theory, probability theory, theory of possibilities and the Dempster-Shafer theory) [6-14]. The basic theory with elaborately worked out rules is the fuzzy set theory. The implementation of alternative approaches in the analysis of uncertainty in design is discussed in the conclusion of the presented paper.

\section{Probabilistic study of tensile member}

The probabilistic evaluation of the design procedure of a steel profile IPE 140 of grade S235 under tension is performed as an illustration.

$$
R_{\mathrm{d}}=\frac{f_{\mathrm{yk}} \cdot A_{\mathrm{n}}}{\gamma_{\mathrm{M}}}=\frac{235 \cdot 10^{6} \cdot 1.64 \cdot 10^{-3}}{1.0}=385.4 \mathrm{kN} \text {, }
$$

where $R_{\mathrm{d}}$ is design resistance calculated according to EUROCODE 3 [15], $A_{\mathrm{n}}$ is the nominal sectional area, $f_{\mathrm{y}, \mathrm{k}}$ is the characteristic value of material yield strength and $\gamma_{M}-$ the material safety factor. 
For the elaboration of the parametric study a simplified problem of tensile member loaded by permanent load combined with single variable load is considered [16]:

$$
F_{\mathrm{d}}=\gamma_{\mathrm{G}} \cdot G_{\mathrm{k}}+\gamma_{\mathrm{Q}} \cdot Q_{\mathrm{k}} \text {. }
$$

It was assumed that the structure is designed for maximum exploitation (economic design), ie $F_{\mathrm{d}}=R_{\mathrm{d}}$. The simplified loading case according to (2) will be considered. The material partial safety factor $\gamma_{M}$ was chosen as the first calibration quantity. The partial safety factors of loading $\gamma_{\mathrm{G}}$ and $\gamma_{\mathrm{Q}}$ were chosen as further calibration quantities.

If the partial safety factors $\gamma_{\mathrm{G}}$ and $\gamma_{\mathrm{Q}}$ are known, characteristic values $G_{\mathrm{k}}$ and $Q_{\mathrm{k}}$ can be determined according to (3) in dependence on the chosen ratio $\delta$, which is given as:

$$
\delta=\frac{Q_{\mathrm{k}}}{G_{\mathrm{k}}+Q_{\mathrm{k}}} .
$$

For permanent action, the Gaussian probability distribution will be assumed, the characteristic value of which, $G_{\mathrm{k}}$, is also the mean value. The variation coefficient 0.1 was assumed according to [16]. For variable action, the Gumbelian distribution with mean value $m_{\mathrm{Q}}=0.6 Q_{\mathrm{k}}$ and standard deviation $S_{\mathrm{Q}}=0.21 Q_{\mathrm{k}}$ was considered.

The analysis of the member reliability is based on the condition that the random load-carrying capacity $R$ is greater than the effects of external forces $F$, expressed by the sum of partial effects $G, Q$ :

$$
R>G+Q \text {, }
$$

where $R$ is the load-carrying capacity of tensile member:

$$
R=A \cdot f_{\mathrm{y}} .
$$

Histograms of the random sectional area $A$ and yield strength $f_{\mathrm{y}}$ obtained from experimental research were published in [1]. The yield strength has the following statistical characteristics: mean value 297.3 MPa, standard deviation 16.8 MPa, skewness 0.32 and kurtosis 2.54. The values were obtained from the evaluation of 562 samples obtained from a third of the flange. This is the standard procedure prescribed by the standards for quality control of metallurgical products. Due to nonzero skewness and kurtosis, the histogram cannot be approximated by the Gaussian probability distribution. The Hermite four parametric distribution, which takes into account the influences of skewness and kurtosis, provides a better approximation of the histogram.

The random sectional area has the following parameters: mean value $1681 \mathrm{~mm}^{2}$, standard deviation $53.2 \mathrm{~mm}^{2}$, skewness -0.215 and kurtosis 3.076 .

In view of the non-zero values of skewness and kurtosis of the yield strength and sectional area the realisations of these variables were simulated from experimentally obtained histograms utilising the Monte Carlo simulation method. 5 million simulation runs of this method were used. The probability that (4) is not fulfilled was evaluated.

\section{Parametric probabilistic analysis}

Three variants of partial safety factor values $\gamma$ were considered in the parametric study.

$$
\begin{aligned}
& \text { 1) } \gamma_{M} \in\langle 1 ; 1.15\rangle, \gamma_{G}=1.35, \gamma_{Q}=1.5 \\
& \text { 2) } \gamma_{M}=1.0, \gamma_{G} \in\langle 1 ; 1.35\rangle, \gamma_{Q}=1.5 . \\
& \text { 3) } \gamma_{M}=1.0, \gamma_{G}=1.35, \gamma_{Q} \in\langle 1.1 ; 1.65\rangle .
\end{aligned}
$$

Values $\gamma_{\mathrm{M}}=1.0, \gamma_{\mathrm{G}}=1.35, \gamma_{\mathrm{Q}}=1.5$ are values listed in standards $[15,16]$. Results of the probabilistic study are depicted in Figs 1-3.

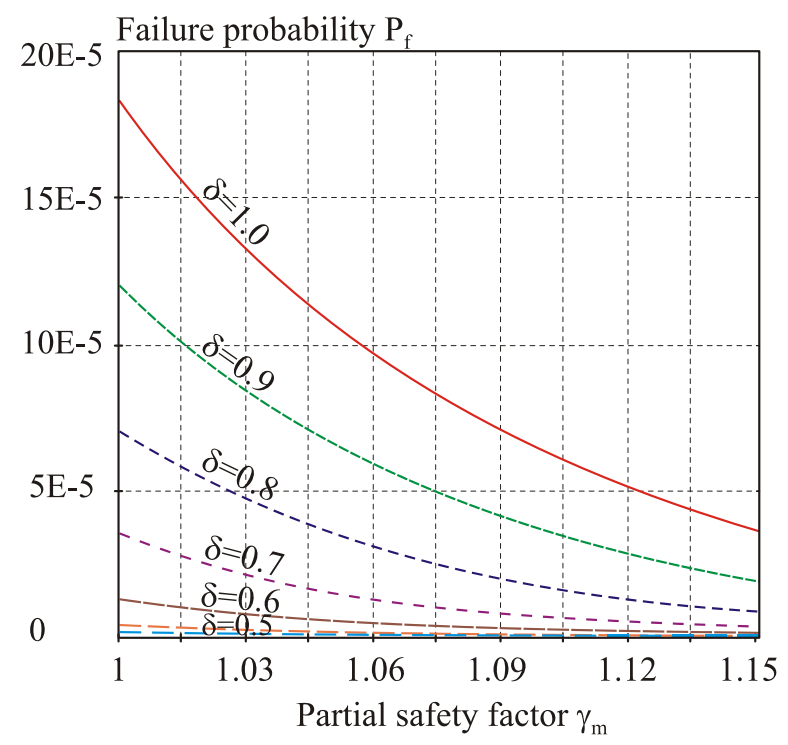

Fig 1. Failure probability $P_{\mathrm{f}}$ versus partial safety factor $\gamma_{\mathrm{M}}$

Only failure probabilities $P_{\mathrm{f}}$ for $\delta>0.3$ are depicted in Fig 1. Failure probabilities $P_{\mathrm{f}}$ pro parameters $\delta \leq 0.3$ are very low and thus insignificant and attest reliable design of the member. Reliability of design is determined by comparing obtained values with the so-called target value given by the standard [16] for reliable design as $P_{\text {fd }}=7.2 \mathrm{E}-5$.

The non-linear behaviour of failure probability versus partial safety factor $\gamma_{M}$ in Fig 1 is very interesting. Reliable design $P_{\mathrm{f}}<7.2 \mathrm{E}-5$ for all $\delta \in\langle 0 ; 1)$ values is secured provided that $\gamma_{M}>1$.1. For light steel structures for which $\delta<0.8$ (majority of real structures), it can be stated that the partial safety factor $\gamma_{M}=1.0$ guarantees sufficiently satisfactory design reliability.

It is evident from Fig 2 that reliable design $P_{\mathrm{f}}<7.2 \mathrm{E}-5$ is guaranteed by $\delta \in\langle 0.15 ; 0.55)$. It is unsafe in the event that $\delta$ approaches zero and $\gamma_{\mathrm{G}}$ approaches 1 . Partial safety factor $\gamma_{G}$ for commonly occurring structures should not be lower than approximately 1.1. The design could otherwise be very unsafe.

It is apparent from Fig 3 that for $\delta<0.8$ (which holds for majority of light steel structures) a sufficiently reliable design is guaranteed by the partial safety factor $\gamma_{\mathrm{Q}}=1.5$. The non-linear behaviour of failure probability, which increases rapidly with decreasing partial safety factor $\gamma_{\mathrm{Q}}$ value, is interesting. 


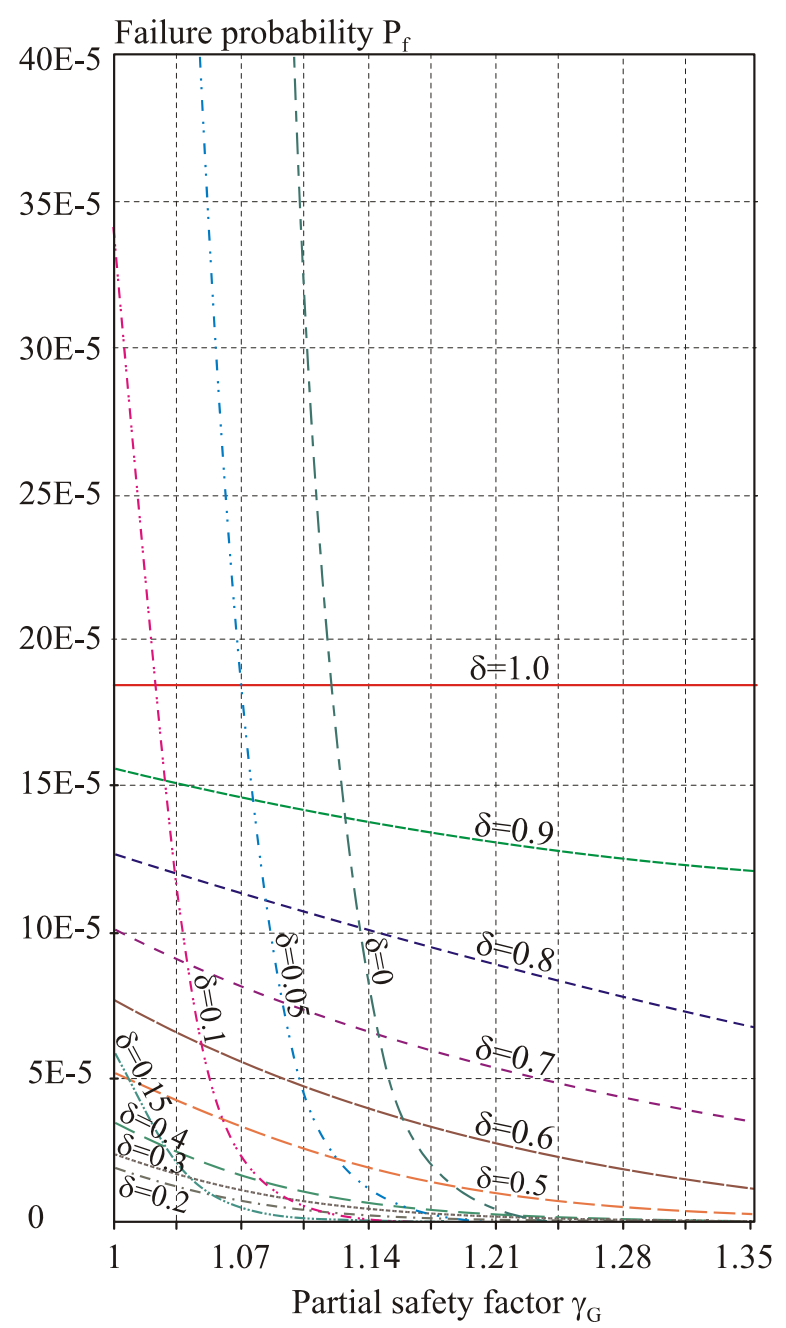

Fig 2. Failure probability $P_{\mathrm{f}}$ versus partial safety factor $\gamma_{\mathrm{G}}$

\section{Fuzzy probability analysis}

For purposes of the quantification of the influence of partial safety factors on the failure probability partial safety factors were considered as fuzzy numbers with linear membership functions (Figs 4-6). Each partial safety factor is assigned a linear degree of membership representing input information for the quantification of the dependence of $P_{\mathrm{f}}$ versus $\gamma$. Fuzzy number supports are assumed similarly as in preceding parametric analysis $\gamma_{M} \in\langle 1.0 ; 1.15), \gamma_{G} \in\langle 1.0 ; 1.35), \gamma_{Q} \in\langle 1.1 ; 1.65)$.

The fuzzy analysis was performed separately for each input fuzzy number $\gamma_{\mathrm{M}}, \gamma_{\mathrm{G}}, \gamma_{\mathrm{Q}}$ utilising the general extension principle [17].

The extension principle may be illustrated on fuzzy number $\gamma \subseteq \mathrm{R}$. Let $\gamma$ be a convex fuzzy number with membership function $\mu_{1}$ and let it be defined by the function $P_{\mathrm{f}}=f(\gamma)$. The degree of membership $\mu_{2}$ of fuzzy number $P_{\mathrm{f}}$ can then be evaluated according to (6):

$$
\mu_{2}\left(P_{\mathrm{f}}\right)=\underset{P_{\mathrm{f}}}{\bigvee} \mu_{1}(\gamma)
$$

The result is fuzzy number $P_{\mathrm{f}}$, containing elements with degree of membership $\mu_{2}$ obtained as the supremum of all $\gamma$ for which $P_{\mathrm{f}}=f(\gamma)$ holds [17].

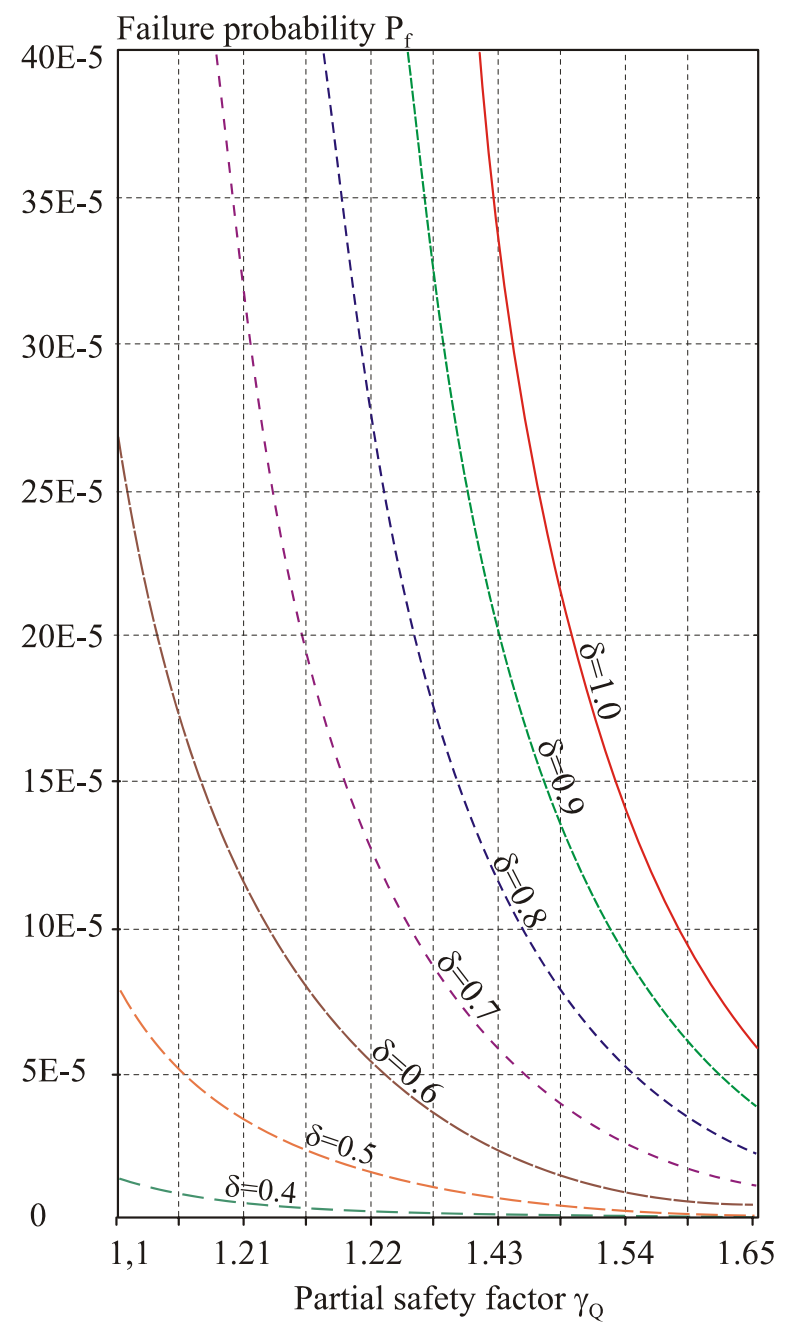

Fig 3. Failure probability $P_{\mathrm{f}}$ versus partial safety factor $\gamma_{\mathrm{Q}}$

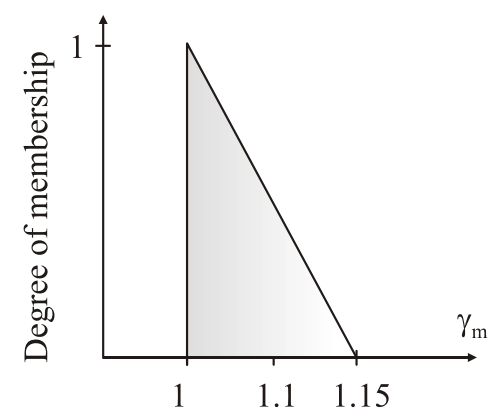

Fig 4. Fuzzy number of partial safety factor $\gamma_{M}$

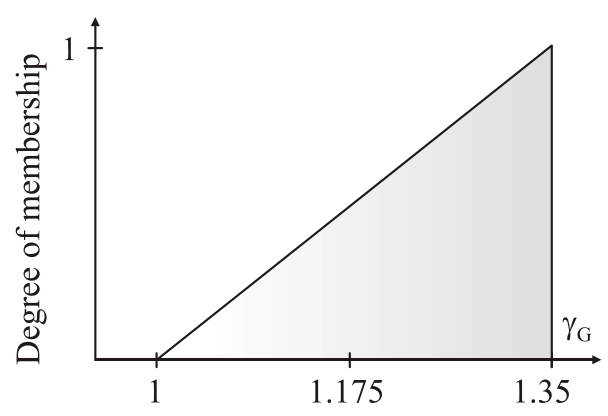

Fig 5. Fuzzy number of partial safety factor $\gamma_{G}$ 


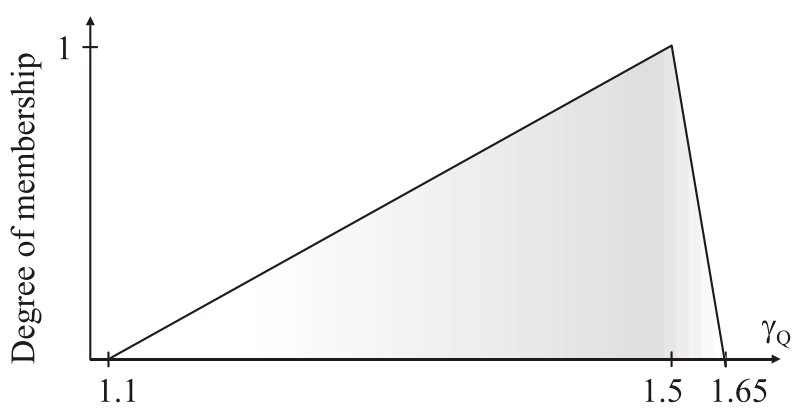

Fig 6. Fuzzy number of partial safety factor $\gamma_{Q}$

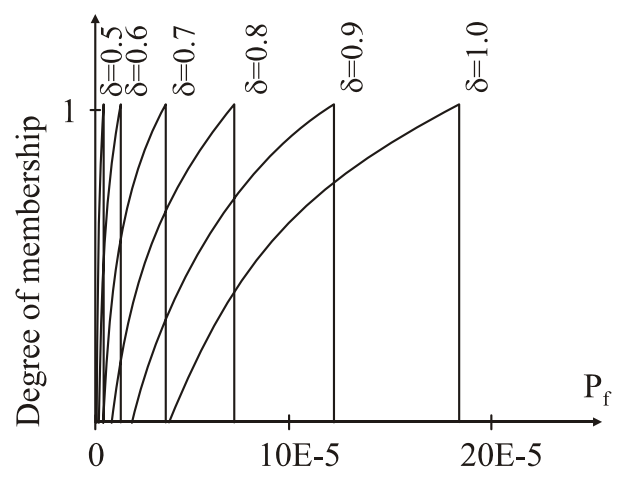

Fig 7. Fuzzy numbers of failure probability due to $\gamma_{M}$

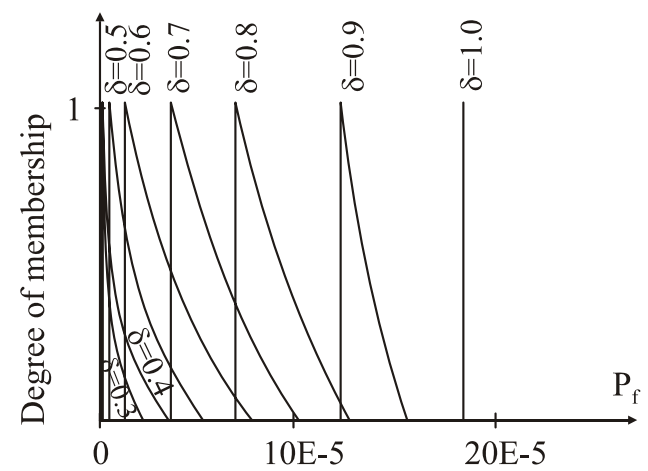

Fig 8. Fuzzy numbers of failure probability due to $\gamma_{\mathrm{G}}$

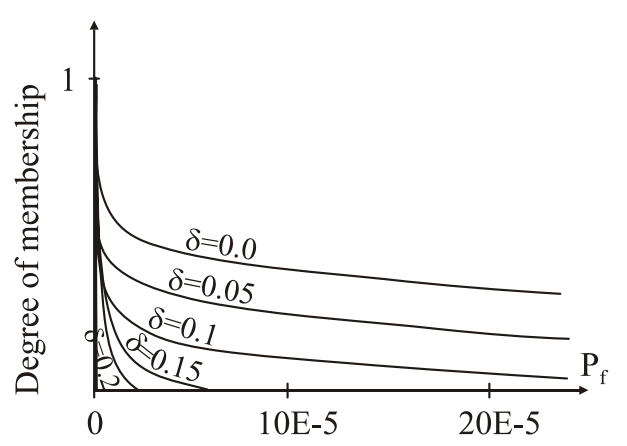

Fig 9. Fuzzy numbers of failure probability due to $\gamma_{\mathrm{G}}$

Fuzzy numbers of failure probabilities corresponding to the fuzzy number of partial safety factor $\gamma_{M}$, (Fig 4) are depicted in Fig 7. It is evident that with decreasing $\delta$ the support of the fuzzy number decreases, as does the kernel value of failure probability.
Fuzzy numbers of failure probabilities corresponding to the fuzzy number of partial safety factor $\gamma_{G}$, (see Fig 5) are depicted in Figs 8, 9. The output fuzzy number for $\delta=1$ (purely variable load) is a singleton, because the partial safety factor of permanent load action $\gamma_{\mathrm{G}}$ has no influence on the value of variable load. In the case of $\delta=0$ (permanent load) the failure probability is significantly influenced by the fuzzy uncertainty of factor $\gamma_{\mathrm{G}}$. This is apparent from the nonlinear behaviours and support sizes.

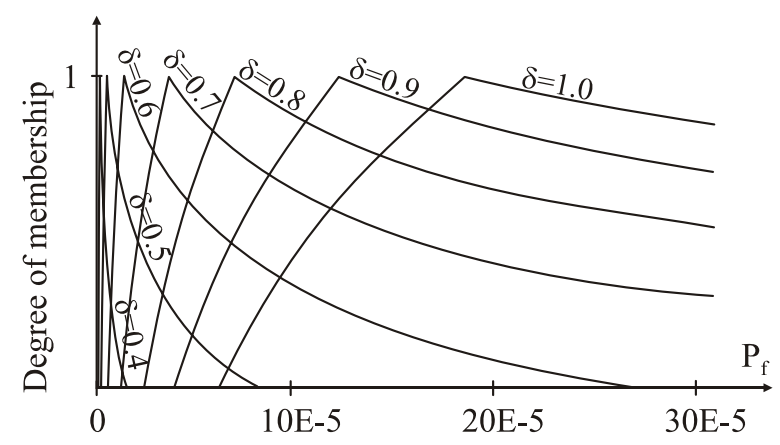

Fig 10. Fuzzy numbers of failure probability due to $\gamma_{Q}$

Fuzzy numbers of failure probabilities corresponding to the fuzzy number of partial safety factor $\gamma_{\mathrm{Q}}$ (see Fig 6) are depicted in Fig 10. It is evident that with decreasing $\delta$ the support of the fuzzy number decreases, as does the kernel value of failure probability.

It is apparent from Figs 7-10 that the output membership functions are non-linear despite linear input membership functions (Figs 4-6). Differences in obtained failure probabilities point out the need for further calibration of partial safety factors.

\section{Conclusions}

Eurocode creation has achieved significant success and acknowledgement even outside the European context. Before long member countries of CEN will design structures according to a unified methodology. The intended high degree of unification of alternative approaches has however not been achieved yet. The Eurocodes will eventually become valid normative standards and the current standards of individual member countries will be cancelled. Increase in reliability and structural durability and also an increase in material consumption can be expected in the Czech Republic. Further refinement of Eurocodes and desired unification of currently alternative approaches is expected.

The verification of partial safety factors using reliability analysis methods was presented in the paper. So far reliability is significantly unbalanced. Probabilistic assessment of reliability pointed out the need for further calibration of partial safety factor values. Limitation to purely probabilistic methods is misleading. Very effective implementation of all available methods of the general uncertainty theory is feasible in reliability analysis [614]. 
Fuzzy analysis was applied to the quantification of the influence of changes in partial safety factors to changes in failure probabilities in the presented paper. Practically output membership functions were nonlinear in all cases.

The presented study pertaining to the simplest case of tensile loading can be applied to more complex loading cases $[18,19]$. In the case of axial compression it is necessary to analyse the ultimate limit state of slender members utilising the geometric non-linear solution with provisions for the influence of initial geometric imperfections of member axis [20]. The limit state is even more complicated for thin-walled structures with regard to problems of loss of stability due to buckling [21-23]. The assessment of reliability of frame structures in the event that system imperfections have an influence on their load carrying capacity is difficult and complicated. Each frame structure (apart from some exceptions) is atypical and the statistical characteristics of system imperfections and their correlation cannot be obtained from experimental research. A number of questions remain unanswered in probabilistic assessment of reliability such as: what density function to use (Gauss, lognormal etc), the correlation between input random variables etc.

Utilisation of probabilistic analysis requires the assignment of exclusively objective statistical information, which however is frequently unavailable. During structural design, information on statistical characteristics of eventual loading is absent. Imprecision (fuzziness) of information on the random initial imperfections and their correlations present a further source of uncertainty. In the event that precise information is unavailable, the model presents a source of vague (fuzzy) uncertainty, which may significantly transcend the stochastic uncertainty in complex systems.

It is pertinent to the discordance between relevance and precision, which was first pointed out by Prof Zadeh when he formulated the so-called principle of incompatibility [24]: "As the complexity of the system increases, our ability to formulate precise and yet significant judgments about its behaviour decreases, until a threshold is reached, beyond which precision and relevance become practically mutually exclusive characteristics".

In this context it is necessary to contemplate as to where the relevant degree of precision of methods for design of structural load bearing structures lays. Despite the fact that solutions of current standards, which are based on the partial safety factor methods (limit states), are not from the point of reliability verification always unambiguously progressive, it will not be displaced from the field of practical application and common design methods for some years. The significance of probabilistic studies is clearly seen especially in the verifications and calibrations of indicators of reliability of EUROCODE standards.

The paper was elaborated under the research projects MSM 0021630519, GAČR 103/07/1067 and Junior Research Project AVCzR KJB201720602.

\section{References}

1. MELCHER, J.; KALA, Z.; HOLICKÝ, M.; FAJKUS, M.; and ROZLÍVKA, L. Design characteristics of structural steels based on statistical analysis of metallurgical products. Journal of Constructional Steel Research, 2004, 60(3-5), p. 795-808.

2. STRAUSS, A.; KALA, Z.; BERGMEISTER, K.; HOFFMANN, S.; NOVÁK, D. Technologische Eigenschaften von Stählen im europäischen Vergleich. Stahlbau, Jan 2006, 75(1), S. 55-60.

3. KALA, Z.; STRAUSS, A.; MELCHER, J.; NOVÁK, D.; FAJKUS, M.; and ROZLÍVKA, L. Comparison of material characteristics of Austrian and Czech structural steels. International Journal of Materials \& Structural Reliability, 2005, 3(1), p. 43-51.

4. KALA, Z. Sensitivity analysis of the stability problems of thin-walled structures. Journal of Constructional Steel Research, 2005, 61(3), p. 415-422.

5. KREJA, I.; MIKULSKI, T.; SZYMCZAK, C. Adjoint approach sensitivity analysis of thin-walled beams and frames. Journal of Civil Engineering and Management, 2005, 11(1), p. 57-64.

6. FETZ, T. H. and OBERGUGGENBERGER, M. Propagation of uncertainty through multivariate functions in the framework of sets of probability measures. Reliability Engineering \& System Safety, 2004, 85(1-3), p. 73-87.

7. HELTON, J. C.; JOHNSON, J. D.; OBERKAMPF, W. L. An exploration of alternative approaches to the representation of uncertainty in model predictions. Reliability Engineering \& System Safety, 2004, 85(1-3), p. 39-71.

8. KOZINE, I. O. and UTKIN, L. V. An approach to combining unreliable pieces of evidence and their propagation in a system response analysis. Reliability Engineering \& System Safety, 2004, 85(1-3), p. 103-112.

9. OBERKAMPF, W. L.; HELTON, J. C.; JOSLYN, C. A.; WOJTKIEWICZ, S. F.; FERSON, S. Challenge problems: uncertainty in system response given uncertain parameters. Reliability Engineering \& System Safety, 2004, 85(1-3), p. 11-19.

10. VERVECKAITE, N.; AMSIEJUS, J.; STRAGYS, V. Stress-strain analysis in the soil sample during laboratory testing. Journal of Civil Engineering and Management, 2007, 13(1), p. 63-70.

11. VIERTL, R. Univariate statistical analysis with fuzzy data. Computational Statistics \& Data Analysis, 2006, 51(1), p. 133-147.

12. MÖLLER, B.; BEER, M.; REUTER, U. Theoretical basics of fuzzy randomness - application to time series with fuzzy data. In Proc of 9th International Conference on Structural Safety and Reliability ICOSSAR'05, Rome (Ita1y), 19-23 June 2005. Ed. G. Augusti, G. I. Schueller and M. Ciampoli. Rotterdam: Millpress, 2005, p. 1701-1707.

13. MÖLLER, B.; BEER, M. Engineering computation under uncertainty - capabilities of non-traditional models. Computers \& Structures, 2007 (in press). Available from Internet: <doi:10.1016/j.compstruc.2007.05.041)>.

14. HOLICKÝ, M. Fuzzy probabilistic models in structural reliability. Maintenance and Reliability, 2006, 2(30), p. 11-13.

15. EN 1993-1-1:2006: Eurocode 3: Design of Steel Structures - Part 1-1: General Rules and Rules for Buildings, CEN. Brussells, Belgium, 2006. 
16. EN 1990 Eurocode: basis of structural design. Brussells, Belgium, 2006.

17. DUBOIS, D.; PRADE, H. Fuzzy sets and systems - theory and applications. New York: Academic Press, 1980, p. 394. ISBN 0-12-222750-6.

18. KARKAUSKAS, R.; NORKUS, A. Truss optimization under stiffness, stability constraints and random loading. Mechanics Research Communications, 2006, 33(2), p. $177-189$.

19. KREJA, I.; MIKULSKI, T.; SZYMCZAK, C. Application of superelements in static analysis of thin-walled structures. Journal of Civil Engineering and Management, 2004, 10(2), p. 113-122.

20. KALA, Z. Stability problems of steel structures in the presence of stochastic and fuzzy uncertainty. Journal of Thin-Walled Structures, 2007 (in print). Available from Internet: <doi:10.1016/j.tws.2007.08.007)>.
21. RASIULIS, K.; SAMOFALOV, M.; ŠAPALAS, A. Application of the non-linear fe models to estimate effect of soft defects on thin walls of steel cylindrical tanks. Journal of Civil Engineering and Management, 2006, 12(2), p. 169-179.

22. RAVINGER, J. and PSOTNÝ, M. Natural vibration of imperfect structures. In Proc of 11th Symposium Stability of Structures, Zakopane, Poland, 2006, p. 345-352.

23. GOROCHOV, Y.; MUSCHANOV, V.; KULIK, A.; TSYPLUKHIN, A. Vertical cylindrical tank with angular geometrical imperfection. Journal of Civil Engineering and Management, 2005, 11(3), p. 175-183.

24. ZADEH, L. A. Outline of a new approach to the analysis of complex system and decision processes. IEEE Transactions on Systems, Man and Cybernetics, 1973, 3(1), p. 2844.

\section{DALINIU SAUGOS KOEFICIENTU ITAKA PLIENO KONSTRUKCIJŲ PROJEKTINIAM PATIKIMIMUI - TIKIMYBE்S IR FUZI TIKIMYBE்S IVERTINIMAS}

\section{Z. Kala}

Santrauka

Straipsnyje nagrinejjama dalinių saugos koeficientu itaka patikimumui projektuojant plieninius elementus. Plieninio elemento patikimumo įvertinimas remiasi realios medžiagos ir geometrinių charakteristikų išsamiais dažniausiai gaminamų produktų eksperimentiniais tyrimais. Medžiaga ir geometriniai parametrai yra atsitiktiniai dydžiai, charakterizuojami histogramomis i̇vertinant patikimumą. Atsitiktinė konstrukcijos dimensijų ir medžiagos parametru variacija veikiama ne vienintele stochastiškumo priežastimi projektuojant pagal standartus. Patikimumas projektuojant plienines konstrukcijas priklauso nuo dalinių saugos koeficientų, parenkamų remiantis projektavimo standartais. Daliniai saugos koeficientai yra indikatoriai, lemiantys apkrautos konstrukcijos dimensijas. Pirmuoju konstrukcijos analizès etapu jos patikimumas nustatomas parametriškai. Suirimo tikimybe analizuojama atsižvelgiant į dalinius saugos veiksnius, skirtus medžiagai, nuolatinėms ir ilgalaikèms apkrovoms. Daliniai saugos koeficientai išreiškiami trikampèmis narystès funkcijomis, naudojamomis antrame konstrukcijos analizès etape. Suirimo tikimybės narystès funkcijos nustatomos naudojant bendraji išskleidimo principą. Pateikiami pagrindiniai rezultatai, apibendrinimai ir taikymas norint patikrinti projektinius ribinių būvių kriterijus.

Reikšminiai žodžiai: plienas, konstrukcija, patikimumas, atsitiktinis dydis, fuzi analizė, netikslumas, modeliavimas.

Zdeněk KALA. Senior Lecturer in Dept of Structural Mechanics, Brno University of Technology, Czech Republic. His research interests include structural safety and reliability, stability problems of structures, FEM - non-linear behaviour of thin-walled structures and fuzzy sets theory. 